Лемешко Ю. Г., Козлова И. Ю.

ОБРАЗ БОГИНИ ЛИНЫШУЙ ФУЖЭНЬ В КОНТЕКСТЕ ЕДИНОГО КУЛЬТУРНОГО

ПРОСТРАНСТВА ПРОВИНЦИИ ФУЦЗЯНЬ И ОСТРОВА ТАЙВАНЬ

Лемешко Ю. Г., Козлова И. Ю.

Y. G. Lemeshko, I. Y. Kozlova

ОБРАЗ БОГИНИ ЛИНЫШУЙ ФУЖЭНЬ В КОНТЕКСТЕ ЕДИНОГО КУЛЬТУРНОГО ПРОСТРАНСТВА ПРОВИНЦИИ ФУЦЗЯНЬ И ОСТРОВА ТАЙВАНЬ

\title{
THE IMAGE OF GODDESS LINSHUI FUREN IN THE CONTEXT OF COMMON CULTURAL SPACE OF FUJIAN AND TAIWAN
}

Лемешко Юлия Геннадьевна - кандидат филологических наук, доцент кафедры китаеведения Амурского государственного университета (Россия, Благовещенск); 675027, г. Благовещенск, Игнатьевское шоссе, 21, +7(4162)394-643. E-mail: ulemeshko@mail.ru.

Ms. Yulia G. Lemeshko - PhD in Philology, Associate Professor, Chinese Studies Department, Amur State University (Russia, Blagoveshchensk); 675027, Blagoveshchensk, 21, Ignatievskoe Rd., +7(4162)394-643. E-mail: ulemeshko@mail.ru.

Козлова Ирина Юрьевна - студентка 3 курса факультета международных отношений Амурского государственного университета (Россия, Благовещенск); 675027, г. Благовещенск, Игнатьевское шосce, 21,+7(4162)394-643. E-mail: irykozlova@gmail.com.

Ms. Irina Y. Kozlova - Third-year Student of the Faculty of International Relations Amur State University (Russia, Blagoveshchensk); 675027, Blagoveshchensk, 21, Ignatievskoe Rd., +7(4162)-394-643. E-mail: irykozlova@gmail.com.

Аннотация. Статья знакомит с результатами исследования культа богини Линьшуй Фужэнь, распространённого в провинции Фуцязнь и на острове Тайвань, описывает историю формирования и его современное состояние.

Summary. The paper deals with the results of the studying the cult of goddess Linshui Furen which is widespread in Fujian province and the island of Taiwan. The article describes the history of its forming and current situation.

Ключевые слова: богиня Линьшуй Фужэнь, провинция Фуцзянь, остров Тайвань, культурное пространство провинции Фуцзянь и острова Тайвань.

Key words: Goddess Linshui Furen, Fujian province, the island of Taiwan, culture of Taiwan and Fujian community.

УДК 745.04

Многими исследователями в КНР понятие миньтай вэньхуа (闽台文化, культура провинции Фуцзянь и острова Тайвань) трактуется как региональная субкультура, которая образовалась на основе культуры центральной равнины (中原文化, чжун'юань вэньхуа) под воздействием географических и исторических факторов. Миньтай вэньхуа представляет собой одну из ветвей культуры центральной равнины, её рассматривают как региональный вид китайской культуры (中华文化, чжунхуа вэньхуа). Хэ Мяньшань характеризует культуру миньтай как одну из семи базовых субкультур китайской нации, которая произошла из «её сердца и была сформирована на основе природно-географических и историко-культурных различий» [15]. Учёный полагает, что понятие миньтай можно трактовать как в широком, так и в узком смысле. В широком смысле рассматриваемая дефиниция обозначает культуру различных районов и родственных этнических групп провинции Фуцзянь и острова Тайвань. В узком смысле миньтай вэньхуа, с одной стороны, является региональной культурой провинции Фуцзянь (в основном её западной и южной частей и районов проживания хакка), 
оказавшей влияние на развитие тайваньской культуры; и с другой - это особая тайваньская культура, возникшая благодаря миграционным процессам, генетически связанная с культурой материка $[15,24]$. Определение, предложенное Хэ Мяньшанем, возможно, наиболее полно раскрывает дефиницию миньтай вэньхуа.

В отечественной синологии рассматриваемая тема остаётся вне сферы интересов ведущих специалистов, степень разработанности проблемы минимальна, до сих пор нет опубликованных работ по интересующим нас вопросам. По причине полного отсутствия теоретических обоснований и сложившегося категориального аппарата для дефиниции миньтай вэньхуа в данной статье мы используем дословный перевод - «культура провинции Фуцзянь и острова Тайвань».

Одним из ведущих исследователей в этой области является профессор Хэ Мяньшань (何绵山, p. 1954), руководитель НИИ региона провинции Фуцзянь и острова Тайвань при Университете радио и телевидения провинции Фуцзянь. В монографии «Региональная культура провинции Фуцзянь и острова Тайвань» [15] учёный рассматривает целый ряд вопросов, связанных с историей её формирования, и уделяет должное внимание описанию современного состояния единого культурного пространства. В «Исследовании культуры региона провинции Фуцзянь и острова Тайвань» он предлагает развёрнутое описание двух сопредельных территорий [14].

Научное обоснование феномена миньтай вэньхуа представлено в книге Линь Гопина «Исследование культуры региона провинции Фуцзянь и острова Тайвань» [5], где автор раскрывает её основные характеристики, особенности религиозных воззрений и сложившихся традиций. Религия, общественные и родовые отношения в этом регионе представлены в работе Лю Дакэ «Исследование общества и народных верований региона провинции Фуцзянь и острова Тайвань» [7].

Особого внимания заслуживает профильный журнал «Исследование региона культуры провинции Фуцзянь и острова Тайвань» (《Миньтай вэньхуа яньцзю», 《闽台文化研究》), с 2005 г. его издаёт исследовательский институт культуры региона провинции Фуцзянь и острова Тайвань при Миньнаньском педагогическом институте г. Чжанчжоу. Журнал публикует научные работы китайских исследователей, посвящённые истории, религии, народным верованиям и литературе региона.

По нашему мнению, в научных изысканиях, посвящённых единому культурному пространству миньтай, могут быть задействованы информационные ресурсы, представленные на специализированном сайте «Фуцзянь и Тайвань онлайн» [9], «Сайте Юго-Востока» [1] и сайте Центра исследования региона провинции Фуцзянь и острова Тайвань [10]. Информация, транслируемая этими сайтами, не является научной и трудно поддаётся классификации, в основном на них публикуют статьи об историческом развитии культуры региона и её современном состоянии. Тем не менее регулярно обновляемые материалы заслуживают нашего к ним обращения, некоторые сообщения и репортажи были использованы при подготовке данной статьи.

В качестве одного из важных факторов осуществления межэтнического диалога в сложившемся едином культурном пространстве выступали религиозные представления и верования жителей провинции Фуцзянь, которые были адаптированы населением острова. В конце XIX - начале XX вв. стараниями переселенцев с материка в городе Тайнань был создан крупнейший на острове центр, производящий ксилографические картины няньхуа. Изучение художественного наследия этого регионального центра «позволяет выделить среди широкого диапазона сюжеты, которые при незначительной вариативности производились и мастерами Тайнаня, и на материке. Это касается прежде всего иконографических образов популярных божеств народных верований Китая - бога домашнего очага Цзао-вана, бога богатства Цай-шэня, духов-хранителей ворот мэнь-шэней» [4]. 
Лемешко Ю. Г., Козлова И. Ю.

ОБРАЗ БОГИНИ ЛИНЬШУЙ ФУЖЭНЬ В КОНТЕКСТЕ ЕДИНОГО КУЛЬТУРНОГО

ПРОСТРАНСТВА ПРОВИНЦИИ ФУЦЗЯНЬ И ОСТРОВА ТАЙВАНЬ

Наряду с самыми популярными божествами народной религии печатали иконы с изображением чадоподательниц, матушек, облегчающих роды, и матушек, оберегающих детей. Материалы о культе почитания матушек-покровительниц детей Ци нянма (七娘媽), распространённом в провинции Фуцзянь и на Тайване, можно найти в статье «Матушкипокровительницы детей на народной картине няньхуа» [3]. Цель данной статьи - раскрыть образ богини Линьшуй фужэнь (临水夫人), которую по значимости сравнивают с небесной императрицей Мацзу. В провинции Фуцзянь её называют Лушан Мащзу (陆上妈祖), т.е. «Мацзу, которая обитает на суше». «В XXI в. в религиозном сознании жителей региона Линьшуй фужэнь по-прежнему остаётся ключевой фигурой, связующим звеном двух берегов» [8].

Реконструкция истории формирования культа Линьшуй фужэнь, как и любого божества из многочисленного пантеона китайских святых, сопряжена с объективными трудностями, первой из которых является слабая источниковая база. Изучив работы китайских исследователей, ссылающихся на письменные источники, рассмотрев статью П. С. Попова «Госпожа Чэнь 陳夫人 Чэнь-фу-жэнь» [11], мы отмечаем, что основной проблемой для изучения образа этой богини является наличие у неё нескольких имён. «Варианты имени Линьшуй фужэнь зависят не только от локализации формирования верований и обрядов, совершаемых в её честь, но и от конкретного исторического периода», - совершенно справедливо указывает Лю Яху в «Словаре народных верований и обычаев» $[18,265]$. Далее мы приводим без изменений все имена женского божества так, как они были представлены в цитируемых нами работах.

Культ Линьшуй фужэнь (имя при рождении Чэнь Цзингу 陈靖姑 или Чэнь Цзиньгу 陈 进姑) был широко распространён в провинции Фуцзянь и прилегающих к ней районах, она была известна как божество, уничтожающее змей-оборотней, и матушка, облегчающая роды. По преданиям, за заслуги ей было пожаловано звание Данай фужэнь (大奶夫人, «госпожа Данай», буквально: «госпожа великая бабушка»), Шунь'и фужэнь (顺懿夫人, «госпожа Шунь'и», буквально: «почтительная и добродетельная госпожа») [18, 265]. Все имеющиеся источники однозначно указывают на место её происхождения - провинцию Фуцзянь. Согласно «Запискам о поисках духов трёх религий и их происхождении», Чэнь Цзиньгу (陈进 姑) родилась в уезде Лоюаньсянь (罗源县) округа Фучжоу в семье императорского сановника, служившего в ведомстве по учёту населения и сбору налогов, её мать носила фамилию Гэ (葛), в семье было два брата - Чэнь Эрсян (陈二相) и Чэнь Хайцин (陈海清). В то время в деревне Линьшуйцунь (临水村) уезда Гутяньсянь (古田县) в волшебной пещере поселилась змея, пожирающая людей. Местные жители были бессильны перед ней, и они выстроили храм для проведения жертвенных обрядов. Ежегодно во время праздника чун'янцзе, чтобы насытить тварь, жители приносили в жертву двух младенцев - мальчика и девочку. Гуаньинь, возвращаясь на остров Хайнань, пролетала над деревней и увидела творящееся там зло. Она отрезала себе ноготь, из которого вышел луч, пронзивший женщину по фамилии Гэ $[18,265]$.

«Записки» повествуют о том, что из луча, пущенного Гуаньинь, зародилась жизнь, в 775 г. 15 числа первого месяца по лунному календарю родилась Чэнь Цзиньгу. Появление девочки на свет сопровождалось счастливыми предзнаменованиями, во время родов её тело озарил свет, по покоям разлились благоухания, в стуке барабанов как будто слышался зов, призывающий небожителей.

Когда девушке исполнилось 17 лет, она разрушила логово ненасытной змеи и заколола её мечом. Кроме того, Цзиньгу помогла танской императрице разрешиться от бремени, состояние императрицы было настолько тяжелым, что она чуть не умерла. Цзиньгу прибыла во дворец, своими заклинаниями облегчила страдания роженицы и спасла жизнь младенцу. Императору доложили о появлении наследника, тот от великой радости пожаловал Чэнь 
Цзиньгу титул «Госпожа великая бабушка Поднебесной, обеспечивающая покой, откликающаяся на мольбы, совершающая добро и дарящая счастье молящимся» (都天镇国显应崇福顺 意大奶夫人). В её честь в уезде Гутяньсянь был установлен храм [18, 266].

В статье «Линьшуй Чэнь фужэнь», включённой в «Полное собрание сведений о небожителях Китая», указаны другая дата и место рождения смертной девушки, ставшей впоследствии божеством: «Чэнь Цзингу (陈靖姑) родилась в деревне Линьшуйцунь уезда Гутяньсянь в 766 г. 15 числа первого месяца по лунному календарю» [17, 457]. Рассказ также базируется на содержании «Записок о поисках духов трёх религий и их происхождении», но он дополнен некоторыми фактами. Старший брат Чэнь Эрсян, получив от явившегося к нему отшельника необычайные дарования, стал обладать уникальными способностями. По просьбе местных жителей, страдающих от змеи, Эрсян должен был убить чудовище. Второй брат Чэнь Хайцин, напившись вина, невольно помешал Эрсяну победить змею, мало того, из-за него Эрсян едва избежал смерти. Семнадцатилетняя Цзингу отправилась в горы для обучения приёмам волшебства, впоследствии она расправилась со змеёй и освободила Эрсяна. Далее следует рассказ о её чудодейственной помощи танской императрице. За заслуги Чэнь Цзингу была включена в пантеон святых матушек, помогающих при родах. Начиная с династии Мин в провинции Фуцзянь повсеместно совершали обряды в её честь $[17,458]$.

Вторая версия происхождения образа Чэнь Цзингу значительно отличается от вышеприведённой. В «Заметках о провинции Фуцзянь» («闽杂记》, «Минь цзацзи»), составленных цинским чиновником Ши Хунбао (施鸿保), можно найти следующую информацию: «Чэнь Цзингу 陈靖姑 (или Чэнь Цзиньгу 陈进姑) родилась в 767 г., её также называли Данай $\phi y-$ жэнь, Чэнь фужэнь, Линьшуй Чэнь фужэнь, Шунь'и фужэнь, Цуйшэн нян-нян (催生娘娘, матушка, ускоряюшая роды), Шуньтянь шэнму (顺天爻母, Матушка, повинуюшаяся воле Неба). Чэнь Цзингу вышла замуж за Лю Ци (刘杞), была беременна несколько месяцев. В то время случилась большая засуха, молодая женщина неустанно молилась о дожде. Ради спасения людей она принесла себя в жертву, ей было только 24 года. Перед смертью Цзингу обещала стать небожительницей, чтобы помогать беременным во время тяжёлых родов» $[16,176]$.

Сюжеты о борьбе Линьшуй фужэнь со змеёй постепенно отошли на второй план, хотя первоначально они занимали заметное место при составлении жизнеописания. Образ святой женщины, помогающей при родах, стал доминировать, составители историй делали акцент на устойчиво реализуемую функцию - родовспоможение. Авторы книги «Божества любви, свадьбы, рождения в изображениях» в составленной ими классификации выделяют в самостоятельную группу святых, которые облегчали роды (助产之神), среди них и Линьшуй фужэнь [13].

Попытки провести анализ имеющихся письменных тестов о земной жизни Линьшуй фужэнь и её сверхчеловеческих способностях, выявить формирование обрядовых практик были предприняты многими учёными КНР в отдельных научных публикациях. В 2014 г. была опубликована книга «Впечатления о богине Линьшуй фужэнь», в которой авторы, обобщив объёмный корпус источников, последовательно изложили истории формирования её культа [2]. В контексте данной статьи будет правильным отметить тот факт, что на презентации книги, прошедшей в уезде Гутяньсянь, присутствовали представители союзов и ассоциаций провинции Фуцзянь и острова Тайвань, деятельность которых нацелена на укрепление культурных связей в регионе.

В отечественной синологии образ Линьшуй фужэнь был описан в «Китайском пантеоне» П. С. Поповым. В параграфе «Госпожа Чэнь 陳夫人 Чэнь-фужэнь» учёный изложил две истории жизни госпожи Чэнь, бытующие на юге Китая. Очевидно, что народная культура, приняв разные версии жизни и деяний Линьшуй фужэнь, распространила её культ среди южан. 
Лемешко Ю. Г., Козлова И. Ю.

ОБРАЗ БОГИНИ ЛИНЫШУЙ ФУЖЭНЬ В КОНТЕКСТЕ ЕДИНОГО КУЛЬТУРНОГО

ПРОСТРАНСТВА ПРОВИНЦИИ ФУЦЗЯНЬ И ОСТРОВА ТАЙВАНЬ

Статья «Данай фужэнь», составленная Б. Л. Рифтиным, базировалась на материалах одного письменного источника, при реконструкции её образа академик апеллировал к конкретной истории жизни молодой женщины, помогающей при родах. Он отмечал, что после смерти она «была канонизирована под именем Цуй-шэн няннян ("матушка, ускоряющая роды")» [12]. Хотя образ Данай фужэнь у Б. Л. Рифтина не соотносится с богиней Линьшуй фужэнь, очевидно, что речь идёт об одном и том же персонаже. Весьма лаконичные сведения о богине можно объяснить локальным характером её культа, сформированного главным образом на основе народных верований провинции Фуцзянь.

Вопрос об иконографии рассматриваемого женского божества достаточно сложен, естественно, что говорить о портретных изображениях Линьшуй фужэнь не приходится. Разные редакции письменных источников, отражающие локальную специфику формирования образа святой, не дают возможности составить представление о её внешности. В цинском Китае бумажные иконы местночтимых божеств обладали рядом стилистических особенностей, как правило, мастера создавали собирательный образ, концентрируя внимание на атрибутах божеств и их окружении. Главным атрибутом Линьшуй фужэнь на бумажных иконах был младенец на руках. Практически все исследователи пишут о том, что «женщины перед родами непременно ставили в комнате её изображение, которое, совершив поклонение, сжигали после омовения ребенка» [12].

Культ Линьшуй фужэнь долгое время носил локальный характер, первый храм в её честь был установлен в 792 г. в уезде Гутяньсянь задолго до сакрализации образа. Принято считать, что здесь была похоронена Чэнь Цзингу. В настоящее время храмовый комплекс Линьшуйгун (临水宫), насчитывающий историю более 1200 лет, является центром по изучению и популяризации женского божества. Рядом с храмом находится большая статуя богини, она держит за руку мальчика, в народе Линьшуй фужэнь называют «божеством, охраняющим женщин и детей» (妇女儿童保护神). Ежедневно к этому сакральному месту стекаются паломники, бездетные женщины взывают о потомстве, беременные обращаются с просьбой о помощи в родах.

С 1999 г. на Тайване функционирует «Общество Матушки, повинующейся воле Неба» (台湾顺天圣母协会, Тайвань иуньтянь шэнму сехуэй), которое организует для верующих поездки в уезд Гутяньсянь для посещения родового храма. Ежегодно в уезде проводят фестивали, посвящённые богине Чэнь Цзингу (陈靖姑文化节), в июне 2015 г. состоялся седьмой фестиваль, на котором верующие из провинций Фуцзянь, Чжэцзян, Гуандун и представители Тайваня приняли участие в ритуальных мероприятиях, организованных храмом. В конце октября 2015 г. в уезде Гутяньсянь при патронаже храма был основан союз культурных связей провинции Фуцзянь и острова Тайвань.

Для верующих Тайваня в 2010 и 2014 гг. были проведены акции, которые позволили им соприкоснуться с важнейшими атрибутами культа - алтарём и позолоченной статуэткой богини. Тысячи тайваньцев встречали богиню, прибывшую из храма уезда Гутяньсянь (古田 临水宫祖庙). В октябре 2014 г. позолоченная статуэтка посетила 28 «филиалов» материкового храма (临水分宫分庙), находящихся в 19 городах и уездах острова, что привлекло более 3 млн тайваньцев. В 2011 г. музей богини Чэнь Цзингу в г. Фучжоу создал представительство в храме Фэн'игун г. Чжунли, что стало первым случаем учреждения на Тайване административного органа фуцзяньской организации народных верований [6].

Система ценностей традиционного Китая предопределила особое место святых чадоподательниц и богинь, охраняющих детей, в религиозном сознании китайцев. Национальнокультурная константа «много сыновей - много счастья» (до изы до фу 多子多福) оказала влияние на формирование социальных установок и культурных универсалий. В настоящее время богине Линьшуй фужэнь поклоняются в 26 странах и регионах, число верующих пре- 
вышает 80 миллионов, в её честь установлено более 5 тысяч храмов, 400 из которых находятся на Тайване [6].

В июне 2008 г. культ богини Чэнь Цзингу (陈靖姑信俗) был внесён Госсоветом КНР в «Список нематериального культурного наследия Китая государственного значения второй категории» (第二批“国家级非物质文化遗产”名录). Региональные власти провинции Фуцзянь, руководители местных вузов и НИИ, учёные, культурологи прилагают всевозможные меры для сохранения и поддержания её культа. В настоящее время зона почитания этой святой и её влияния на религиозную жизнь главным образом ограничивается регионом распространения культуры миньтай. В этом контексте верования сакрализация храмов, обрядовые практики, связанные с культом Линьшуй фужэнь, являются одной из важных составляющих кросскультурного взаимодействия юга материкового Китая и острова Тайвань.

\section{ЛИТЕРАТУРА}

1. Дуннань ван (Сайт Юго-Востока) [Электронный ресурс]: офиц. сайт. - Режим доступа: http://www.fjsen.com. 东南网.

2. Иньсян Линьшуй фужэнь / Чжэн Аньсы, Чэнь Цзянь чжубянь. Фучжоу: Хайся шуцзюй, 2014 (Впечатления о богине Линьшуй фужэнь / ред. Чжэн Аньсы, Чэнь Цзянь. Фучжоу, 2014. - 132 с.) 印象临 水夫人 / 郑安思, 陈健主编. - 福州: 海峡书局, 2014. - 132 页.

3. Лемешко, Ю. Г. Матушки-покровительницы детей на народной картине няньхуа / Ю. Г. Лемешко // Общество и государство в Китае. T. XLV. Ч. 1 / редкол.: А. И. Кобзев [и др.]. - М.: ИВ РАН, 2015. - С. 490-497.

4. Лемешко, Ю. Г. Региональный центр народной картины няньхуа на Тайване / Ю. Г. Лемешко // Исторические, философские, политические и юридические науки, культурология и искусствоведение. Вопросы теории и практики. - 2015. - № 1 (51). Ч. 1. - С. 106.

5. Линь Гопин. Миньтай цюйюй вэньхуа яньцзю. - Бэйцзин: Чжунго шэхуэй кэсюэ чубаньшэ, 2000. (Линь Гопин. Исследование культуры региона провинции Фуцзянь и острова Тайвань. - Пекин, 2000. 526 c.) 林国平. 闽台区域文化研究. 北京: 中国社会科学出版社, 2000. - 526 页.

6. Линьшуй фужэнь Чэнь Цзингу: лян'ань синьчжун гунфэн дэ миньсу синьян (Линьшуй фужэнь Чэнь Цзингу: народные обычаи и верования верующих Китая и Тайваня) // Хуася цзинвэй - онлайн. URL: http://www.huaxia.com/zhwh /msdl/tw/2014/12/4171067.html (дата обращения: 25.01.2015).

7. Лю Дакэ. Миньтай ди’юй жэньцюнь юй миньцзянь синьян яньцзю. - Фучжоу: Хайфэн чубаньшэ, 2008. (Лю Дакэ. Исследование общества и народных верований региона провинции Фуцзянь и острова Тайвань. - Фучжоу, 2008. - 342 c.) 刘大可. 闽台地域人群与民间信仰研究. 福州: 海风出版社, 2008. 342 页.

8. Лянь Чжэньбяо. Доюань фухэдэ цзунцзяо вэньхуа исян - Линьшуй фужэнь синсян танькао // Шицзе цзунцзяо яньцзю, 2005. - № 1. (Лянь Чжэньбяо. Разносторонний комплексный образ религиозной культуры - исследование образа богини Линьшуй фужэнь // Изучение религий мира. - 2005. - № 1. C. 129-141.) 连镇标. 多元复合的宗教文化意象 - 临水夫人形象探考 // 世界宗教研究，2005, 第 1 期, 129-141 页.

9. Миньтай цзай сянь Чжунго Тайвань ван (Фуцзянь и Тайвань онлайн - сайт Китая и Тайваня) [Электронный ресурс]: офиц. сайт. - Режим доступа: www.fj.taiwan.cn /. 闽台在线 - 中国台湾网.

10. Миньтай цюй'юй яньцзю чжунсин (Центр исследования региона провинции Фуцзянь и острова Тайвань) [Электронный ресурс]: офиц. сайт. - Режим доступа: http:// www.mtrc99.net. 闽台区域研究 中心.

11. Попов, П. С. Китайский пантеон / П. С. Попов. - СПб.: тип. Имп. Акад. наук, 1907. - 88 с.

12. Рифтин, Б. Л. Данай фужэнь / Б. Л. Рифтин // Мифы народов мира. Энциклопедия. В 2 т. Т. 1. А - К / гл. ред. С. А. Токарев. - М.: Российская энциклопедия, 1994. - С. 349-351.

13. Тушо айцин хунь юй шэнь / Инь Вэй, Чэн Цзяньцян бяньчжу. - Бэйцзин: Цинхуа дасюэ чубаньшэ, 2014. (Божества любви, свадьбы, рождения в изображениях / Инь Вэй, Чэн Цзяньцян. Пекин, 2014. 196 c.) 图说爱情婚育神/殷伟, 程建强. - 北京: 清华大学出版社. - 196 页. 
Лемешко Ю. Г., Козлова И. Ю.

ОБРАЗ БОГИНИ ЛИНЬШУЙ ФУЖЭНЬ В КОНТЕКСТЕ ЕДИНОГО КУЛЬТУРНОГО

ПРОСТРАНСТВА ПРОВИНЦИИ ФУЦЗЯНЬ И ОСТРОВА ТАЙВАНЬ

14. Хэ Мяньшань. Миньтай вэньхуа тань люэ. - Сямэнь: Сямэнь дасюэ чубаньшэ, 2005. (Хэ Мяньшань. Исследование культуры региона провинции Фуцзянь и острова Тайвань. Сямэнь, 2005. - 242 с.) 何绵山. 闽台文化探略. 厦门: 厦门大学出版社. -242 页.

15. Хэ Мяньшань. Миньтай цюйюй вэньхуа. - Сямэнь: Сямэнь дасюэ чубаньшэ, 2004 (Хэ Мяньшань. Региональная культура региона провинции Фуцзянь и острова Тайвань. Сямэнь, 2004. - 331 с.) 何绵 山. 闽台区域文化. 厦门: 厦门大学出版社, 2004. - 331 页.

16. Чжунго миньцзянь сушэнь / Инь Вэй, Инь Фэйжань чжу. - Куньмин: Юньнань жэньминь чубаньшэ, 2003. (Народные обычаи и божества Китая / ред. Инь Вэй, Инь Фэйжань. - Куньмин, 2003. - 332 c.) 中国民间俗神 / 殷伟, 殷斐然著. 昆明: 云南人民出版社, 2003. - 332 页.

17. Чжунго шэньсянь дацюань / Лэн Ли, Фань Ли чжубянь. - Шэньян: Ляонин жэньминь чубаньшэ, 1990. (Полное собрание сведений о небожителях Китая / ред. Лэн Ли, Фань Ли. - Шэньян, 1990. 508 c.) 中国神仙大全 / 冷立, 范力编著. 沈阳: 辽宁人民出版社出版. 1990. - 508 页.

18. Чжунго миньцзянь синь'ян фэнсу цыдянь / Ван Цзинлинь, Сюй Тао чжубянь. - Эр бань. Бэйцзин: Чжунго вэньлянь чубань гунсы, 1997. (Словарь китайских народных верований и обычаев / ред. Ван Цзинлинь, Сюй Тао. - 2-е изд. - Пекин, 1997. - 883 с.) 中国民间信仰风俗辞典/ 王景琳，徐 匋主编. -2 版. - 北京: 中国文联出版公司, 1997. -883 页. 